\title{
FOTOGRAFIAS TUMULARES EM UMA ANTIGA COLÔNIA DE ISOLAMENTO SANITÁRIO: SOBREVIVÊNCIAS DE UM PASSADO EM DESAPARECIMENTO
}

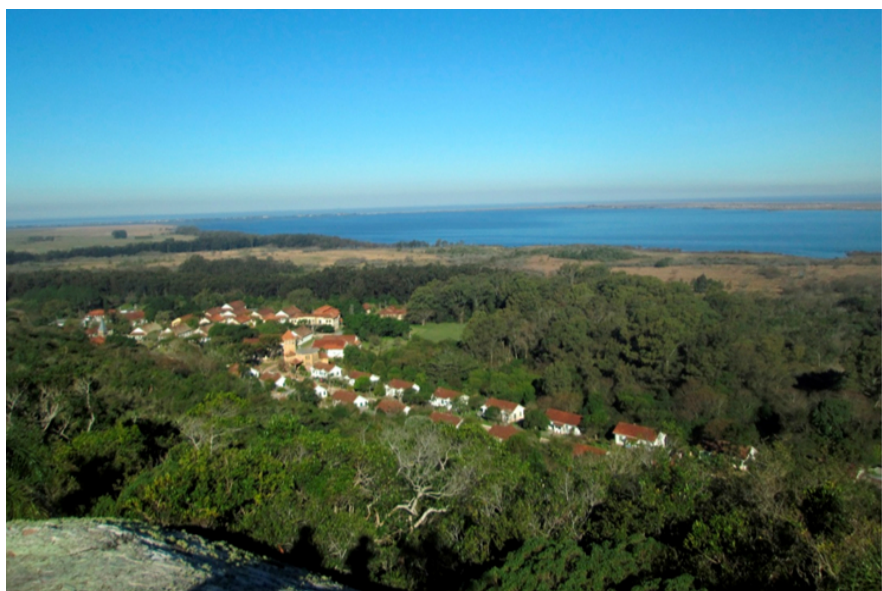

\section{Daniele Borges Bezerra ${ }^{1}$ Cláudia Turra Magni}
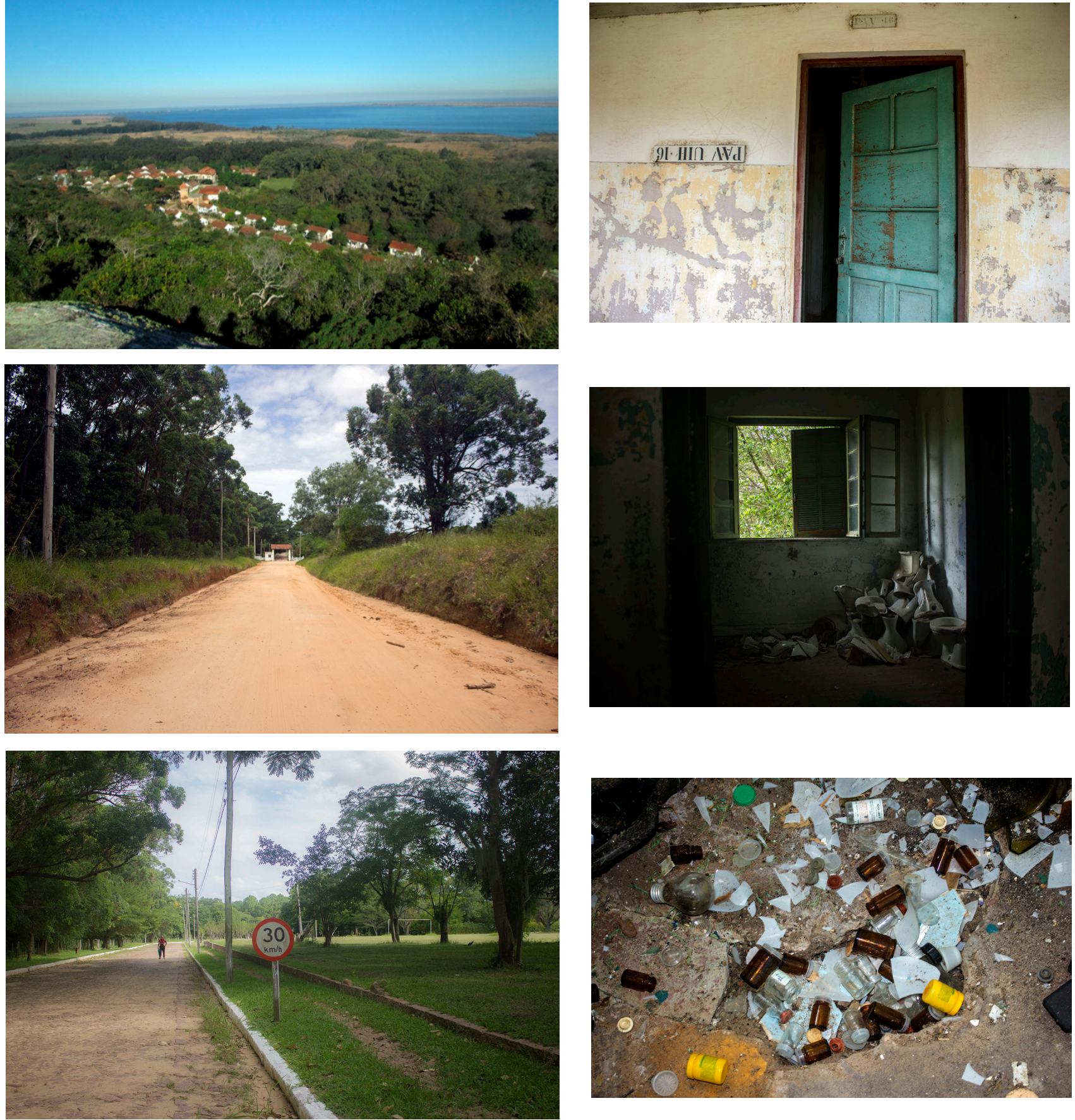

Imagem 1. Prancha montada a partir de fotografias do lugar e seus restos do HCI, 2018. Acervo: Daniele Bezerra, 2019.

\footnotetext{
${ }^{1}$ Universidade Federal de Pelotas, Brasil. Email: borgesfotografia@gmail.com ORCID id: https://orcid.org/0000-0001-6278-3838

${ }^{2}$ Universidade Federal de Pelotas, Brasil. Email: clauturra@yahoo.com.br ORCID id: https://orcid.org/0000-0002-3478-7708
} 


\section{Imagens em isolamento: Arquivos de arquivos}

A fotografia, enquanto arquivo visual, compara-se a lascas do tempo (Cf. DidiHuberman, 2013) que nos chegam pelo artifício da montagem, sobrevivências em imagens, poeira do tempo depositada sobre uma superfície sensível e ressonância afetiva. É isso o que este artigo pretende demonstrar, ao propor a montagem "verbovisual" (Bruno, 2007) como uma epistemologia da imagem que permite conhecer, interpretar e dar a ver uma dimensão pouco conhecida da política sanitária brasileira ${ }^{3}$, qual seja, o isolamento compulsório em hospitais-colônia, microcidades obsoletas ${ }^{4}$, criadas para impedir a contaminação pela, outrora temida, lepra, hoje conhecida como hanseníase. Nestes locais, o longo tempo de internação e a estigmatização fez com que a reinserção social, após a cura, em muitos casos, não acontecesse, e muitos internos permaneceram morando nas colônias, de modo que os cemitérios criados nesses locais se tornaram sua morada definitiva.

Ao dedicar-se à memória destas pessoas, a partir de suas narrativas orais e álbuns pessoais, da documentação institucional ${ }^{5}$ e da observação flutuante (Petonnet, 2008) acompanhada do registro fotográfico nas ruínas daquela microcidade, Daniele Borges Bezerra (2019), co-autora deste artigo, propõe conceber suas narrativas verbovisuais enquanto arquivos, um lugar de pensamento e um meio de transmissão para memórias difíceis. Neste artigo, nos deteremos no Hospital-Colônia Itapuã (HCI), localizado na cidade de Viamão (RS), mais especificamente no caso de seu cemitério. Para os últimos habitantes da localidade, mais que um lugar de culto, o cemitério é o recordatório do desaparecimento dos seus companheiros de infortúnio, o que coincide com o esvaziamento do espaço habitado. Assim, ao entendermos tais cemitérios como redobramento do esquecimento e da invisibilidade, destacamos a fotografia tumular

\footnotetext{
${ }^{3}$ Referimo-nos ao caso brasileiro porque enfocamos as experiências narradas no Hospital-Colônia Itapuã (RS), mas reforçamos que essa foi uma política transnacional, e mesmo a política adotada no Brasil teve como referência as deliberações e recomendações extraídas das conferências internacionais sobre a lepra (Cf. Bezerra, 2019).

${ }^{4}$ No Brasil o modelo de isolamento do tipo asilo-colônia começou a ser implementado na década de 1920 e teve seu auge entre as décadas de 1940 e 1960. Tais hospitais, continham o necessário para a vida dentro das fronteiras de seu território, impedindo o contato com a parcela saudável da população. Em função de suas características constitutivas e espaciais, tais lugares podem ser entendidos como "instituições totais" (Goffman, 2003).

${ }^{5}$ Referimo-nos à documentação organizada pela professora Juliane Conceição Primon Serres no período em que participou da organização do CEDOPE/HCI. A documentação consultada faz parte do acervo pessoal da professora Juliane Serres (PPGMP-UFPel), que realizou sua pesquisa de mestrado e doutorado no local.
} 
como signo dos não ditos, no processo de apagamento de presenças socialmente indesejáveis. Nesse contexto, em que o passado melhor preservado é o que integra o memorial da instituição, entendemos o cemitério como parte do processo de arruinamento do lugar, uma cicatriz deixada por tal política, mais do que um lugar de culto aos mortos. As inscrições cemiteriais, sobretudo as fotografias, estes vultos que nos olham, como sobrevivências do passado, começam a perder seu potencial de rastro, tornando-se o que Fabiana Bruno (2018) designa como "imagens órfãs", mas que, apesar de tudo, parecem resistir ao esquecimento, tal como fantasmagorias do isolamento compulsório.

Consideramos a função de ancoragem da memória, proposta por Roland Barthes ao afirmar que "a fotografia traz sempre consigo o seu referente" (Barthes, 2010: 13) e temos presente que a fotografia não é representação cristalizada do real, mas possui uma dinâmica viva e resiste às manipulações de quem a produziu, tanto quanto de quem procura decifrá-la (Rancière, 2014: 124). A essas considerações acrescemos a tese sustentada por Bezerra (2019) ${ }^{6}$ de que a fotografia também pode configurar-se como um "monumento-refratário" com a faculdade anacrônica de transmissão de distintas temporalidades, o que permite tornar legível e comunicável uma ínfima parcela de tais experiências.

O que primeiro nos revela esse arquivo de imagens ${ }^{7}$, gerado a partir das fotografias tumulares do Hospital-Colônia Itapuã, é o desejo de memória, expresso pelo reforço da identificação do túmulo. Uma ilusão de proximidade, que ressalta o poder de identificação ${ }^{8}$ atribuído aos retratos também após a morte, como extensões do eu, uma espécie de "memória prótese" (Cf. Derrida, 2001; Landsberg, 2004; Robin, 2016) que promove uma ligação entre o mundo dos vivos e a memória dos mortos.

\footnotetext{
${ }^{6} \mathrm{O}$ monumento refratário, enquanto signo, não ilustra nem corresponde ao real, mas conduz ideologias, e refrata (BAKHTIN, 2006) realidades distintas, tendo como suporte as narrativas visuais e as narrativas verbais. São essas narrativas que provocam a refração da realidade a ser transmitida. Na tese intitulada $A$ ressonância afetiva das memórias como meio de transmissão para um patrimônio difícil: monumentos em antigos leprosários (BEZERRA, 2019), o monumento refratário não é apenas um instrumento de transmissão que evidencia o caráter de resistência inerente às narrativas (verbais e visuais) e à arte como linguagem por onde elas ressoam, mas é, sobretudo, um dispositivo de visibilidade capaz de provocar afecção e pensamento.

${ }^{7}$ As fotos foram realizadas pela autora da tese, Daniele Borges Bezerra, com um dispositivo móvel, durante uma visita de campo exploratória ocorrida em 2015.

${ }^{8}$ Antes de se popularizar como prática no cotidiano, a fotografia foi utilizada como instrumento de estudo dos estados afetivos e de identificação de formas anatômicas associadas a perfis criminosos (Cf. DidiHuberman, 1982; Medeiros, 2010), sendo naturalizada mais tarde como parte do documento de identificação civil.
} 
Ao comparar a fotografia com o brilho de uma estrela, Roland Barthes deixa clara sua posição com relação ao passado contido nas imagens, haja vista que a estrela continua a emanar suas radiações de presença, mesmo após a sua extinção: "isto foi" (Barthes, 2010:89). Na mesma direção, Walter Benjamin fala da imagem como uma constelação (Benjamin, 2018), de modo que, enquanto nossa relação com o passado é temporal, a relação do "ocorrido com o agora é dialética - não de natureza temporal, mas imagética". Portanto, para Benjamin, "a imagem é a dialética da imobilidade" (idem: 768) e da reapresentação por onde emanam as memórias. Paradoxalmente, por estarem continuamente abertas ao pensamento e às interpretações do presente, as imagens podem ser entendidas como pensamentos móveis que produzem novas memórias e novos arquivos. Arquivos de arquivos, afinal.

Nesse ínterim, revisitadas ao logo dos quatro anos do desenvolvimento da pesquisa de doutorado e manipuladas a partir do princípio da montagem, desmontagem e remontagem, tais imagens, em diálogo com os interlocutores da pesquisa e com os pares da academia, acionaram o pensamento e promoveram meios para a compreensão da experiência humana de isolamento no espaço. Ou seja, para além de seu objetivo inicial de evocação da memória pela identificação dos mortos, aquelas fotografias tumulares permitiram vislumbrar as marcas deixadas pelas relações entre as pessoas isoladas e o ambiente do hospital hoje em ruínas. Mais que isso, elas nos fazem pensar a respeito daquela política de saúde pública e de suas implicações individuais e coletivas sobre os destinos de milhares de pessoas marcadas pelo estigma da lepra.

\title{
A identificação tumular nos cemitérios do Ocidente
}

\begin{abstract}
[...] via-me assediado por rostos imprevistos, vindos de longe, que me fixavam como se quisessem ser reconhecidos, como se quisessem me reconhecer, como se houvessem me reconhecido. Pode ser que eu também lhes recordasse alguém morto (Calvino, 2009:90).
\end{abstract}

A introdução dos retratos cemiteriais, que passaram a personificar os túmulos a partir do século $\mathrm{XIX}^{9}$, reforçou o caráter memorial do culto aos mortos a partir de uma

\footnotetext{
${ }^{9} \mathrm{O}$ uso dos retratos tumulares impressos sobre porcelana, como conhecemos hoje, começou a ocorrer na metade do século XIX, menos de duas décadas após a invenção da primeira técnica moderna de fotografia, a chamada daguerreotipia, que foi tornada pública em 1839. O método de fixação da imagem fotográfica sobre porcelana esmaltada foi patenteado pelos franceses André François Bulot e Joseph Marguerite Cattin, na Inglaterra, em 1854 (Haydon, 2008). Segundo as pesquisas de Lisa Montanarelli (apud Horne; Montanarelli, 2004), os imigrantes italianos do início do século XX teriam sido os
} 
dupla inscrição que agrega às mensagens póstumas - e às informações sobre o falecido - a reprodução da persona do morto por meio de seu retrato. O sociólogo francês Marcel Mauss localiza o surgimento da noção de pessoa no início da civilização latina, associada à palavra persona, que designava “[...] máscara, máscara trágica, máscara ritual e máscara de ancestral" (Mauss, 2011: 383). Assim, "persona vindo de per/sonare" (idem: 385) é a máscara por onde a voz ressoa. Com base nisso, Mauss reconhece a categoria "pessoa" como personagem do meio social, uma forma de ser e estar no "jogo", que nasce intimamente ligada ao direito de fala. Ou seja, a inscrição social da pessoa como sujeito de direito. No caso do isolamento compulsório em antigos leprosários, num contexto de políticas inclusivas, o direito à identidade e à memória se impõem como uma questão ética, em que o reconhecimento do passado de sofrimento deve estar aliado à nomeação dos mortos e ao reconhecimento destas memórias subterrâneas.

Para Roland Barthes, citando Calvino, é a máscara “[...] que faz de um rosto o produto de uma sociedade e da sua história” (Barthes, 2010: 43). Pois a máscara, como mediação de uma presença no mundo, permite a criação de uma identidade social, que também resulta dessa ação em sociedade. A máscara ancestral, feita em cera sobre o rosto do falecido, denominada "imago" (Mauss, 2011: 387) deu origem ao termo imagem e está na base da noção do "eu”, localizado entre a comédia e a tragédia, o autêntico e o simulacro, a presença e a ausência. Para Didi-Huberman (1998b), a morte significa-se pelo esvaziamento, e o retrato, independentemente de gênero ou propósito, desempenha uma função estabilizadora, simbólica, ocupando o lugar do rosto ausente. Em relação aos retratos cemiteriais que ornamentam as lápides, esse simbolismo é completo e objetivo, na medida em que, além de identificar, eles sinalizam a ausência. Com o retrato tumular, retomamos o princípio da máscara mortuária como imagem gerada para representar uma pessoa. A representação é, em si, um colocar em cena, um dar a ver, um meio de simbolizar o referente. Os signos, por outro lado, trazem traços e sintomas do seu referente, carregando uma proximidade. Por esse ângulo, os retratos cemiteriais possuem o duplo poder de representar um rosto ausente e de apresentar uma distância, que permite conectar emocionalmente o olhar do presente aos traços conservados do referente.

primeiros a exibir esse tipo de retrato cerâmico de entes falecidos, tanto em lápides, como nas paredes das próprias casas. 
Longe, então, de mostrar puramente a representação plena dos rostos, o que os retratos fariam depois de tudo seria apenas poetizar - isto é, produzir - uma tensão sem recurso entre a representação dos rostos e a difícil gestão de sua perda, ou de sua espécie de esvaziamento interior (Didi-Huberman, 1998b: 62).

Para dar destaque a isso observamos que, nos primórdios da invenção das representações visuais, há uma relação direta com a ideia de impressão, indício e ausência, mas também de presença e de memória. $\mathrm{O}$ mito da pintura, apresentado por Plínio no livro 35 da obra Historia naturalis (apud Dubois, 2012), permite antever essa particularidade do registro. Nesse mito, um jovem casal, à beira de uma fogueira, prepara-se para a despedida. Com a intenção de reter a presença do amado, que deve se ausentar por algum tempo, a mulher registra a silhueta do corpo do homem com carvão. O resultante desse processo é a demarcação de uma ausência, conservada pelos traços, indícios de uma presença que foi e não é mais. Da mesma forma, a impressão das mãos na caverna de Lascaux, ${ }^{10}$ evidencia vazios e não cheios, já que as marcas não resultam do contato por fricção, mas dos pigmentos soprados sobre as mãos que, ao serem retiradas, revelam o espaço que elas ocupavam.

Em sua constituição inicial, a fotografia possui esse caráter de índice, que nos ilude com a presença fantasmagórica do referente, um duplo que, em outro suporte, torna-se signo de uma presença do passado, lembrança de uma lembrança e lugar de depósito (Debary, 2017). No nosso campo de estudo, a fotografia, mas também o espaço do cemitério e as narrativas dos moradores, não deixam de emanar seus referentes (Barthes, 2010). Mas, as fotografias tumulares, já independentes de seus referentes, destacadas do ritual narrativo das visitas em dias de finados, por exemplo, cumprem sua última função arquivística, passando a simbolizar a ausência, mais do que a apresentar uma presença. São fantasmagorias de pessoas com as quais gostaríamos de nos familiarizar, mas que já não podem narrar. Suas informações foram seladas pela instituição, são matéria privilegiada da ética institucional que arbitra, também, sobre a memória dos mortos. E, não obstante, estas imagens se impõem, resistem ao silêncio e contrariam a invisibilidade programada das colônias.

Para Barthes, a fotografia confirma a existência daquilo que apresenta, por isso tem algo de "ressurreição" (Barthes, 2010: 93). É para essa natureza aurática das imagens que Walter Benjamin (1987: 174) chama a atenção, destacando a importância

\footnotetext{
${ }^{10}$ Didi-Huberman chama a atenção para a ausência da representação do rosto humano em Lascaux, sendo a única imagem presente (bisonte ferido) uma simplificação das formas humanas, onde a cabeça do humano representado tem a aparência de uma cabeça de pássaro. Isso não invalida a representação como um “[...] signo sensível de nossa presença no universo” (Bataille apud Didi-Huberman, 1998b: 63).
} 
do retrato no culto aos mortos como mais um sintoma do século XIX. Nesse sentido, tanto a sepultura como a fotografia são rastros de onde a presença se retirou. Observamos, no entanto, que ambas possuem naturezas distintas em sua relação com a memória, pois a sepultura e os restos mortais que ela guarda são vestígios, ou seja, "o aparecimento de uma proximidade" (Benjamin, 1989: 226), enquanto a aura, que se apreende pela fotografia, "é o aparecimento de uma distância" (idem, ibidem).

Dito de outra forma, é a sensação de presença de algo distante no tempo. Por isso temos a impressão de que os rostos nas lápides querem nos dizer algo, porque a aura tem o poder de introduzir no espaço essa distância que age "[...] sobre o nosso olhar, sobre nossa capacidade de nos sentirmos olhados" (Didi-Huberman,1998: 164). Pois, "no vestígio, apossamo-nos da coisa; na aura, ela se apodera de nós" (Benjamin, 1989: 226).

No livro Cascas, Didi-Huberman (2013) critica a institucionalização do horror na forma de história musealizada. Diante das manipulações pelas quais as fotografias feitas por membros do sonderkommando passaram para chegar ao lugar de exposição, ele discute seu teor documental. Consideradas como "os únicos testemunhos visuais de uma operação de asfixia por meio do gás" "11 (Didi-Huberman, 2013:46) estas imagens resultam do desejo de transmissão que motivou o operador da câmera a expor-se ao perigo do registro, o "vital perigo de presenciar o que acontecia em Birkenau" (idem: 48). Essa discussão é importante, porque ilustra o problema da domesticação do passado, o que pode promover o apagamento de testemunhos materiais espontâneos, carregados de significado.

Não por acaso, o símbolo utilizado pelos idealizadores do Museu do Estado de Auschwitz-Birkenau para a exibição das fotografias foi a lápide, lugar de nomeação e homenagem aos mortos. Ao longo do texto, Didi-Huberman refere-se tanto à lápide quanto às fotografias como "lugares de memória" (Didi-Huberman, 2013), o que reforça nosso argumento de que o retrato cemiterial, enquanto dispositivo intencional de memória, também é um tipo de monumento, assim como o túmulo, símbolo material da memória que guarda. Pois, num nível simbólico, mas também operacional, objetivo, as foto-memórias têm o mesmo princípio do monumento. Feitas para lembrar, chamam a nossa atenção e nos convidam a uma imersão em outra temporalidade, como se nos “acenassem". Quando entramos num cemitério, sentimo-nos como se estivéssemos em

${ }^{11}$ Tradução da autora para: "les seuls témoignages visuels d'une opération de gazage”. 
Adelma, a cidade de Ítalo Calvino (2009), onde o visitante sente-se rodeado por pessoas do passado.

Ao admitirmos que as imagens "[...] trabalham, que reacendem velhas lembranças e outras imagens" (Samain, 2012: 161) e que elas, sobretudo, "interrogam nosso tempo presente" (idem), percebemos que "as memórias de arquivos são sempre questões postas diante de nossa história, interrogações que olham para nós" (idem, ibidem). Desse modo, as fotografias - e as fotografias tumulares em particular - não são apenas evocadores, mas, também, porções arquivadas do tempo que trazem novas indagações ao presente. Essas imagens fantasmagóricas que coabitam o espaço dos vivos como aparições em pequenas fagulhas, nos fazem refletir sobre o tempo, a gestão das memórias e a pujança do estigma nas políticas-sanitárias autoritárias. E, nesse sentido, fica a questão para apreciação individual de cada olhar/leitura: afinal, o que nos interrogam, como nos interpelam as fotografias tumulares, dentro do que resta dos hospitais-colônia? O que pensariam os vultos nas imagens, sobre esse lugar, suas narrativas de passado e suas possibilidades de futuro?

\section{Fotografias tumulares no Hospital-Colônia Itapuã e o processo de tornar-se órfãs}

\section{O silêncio é ausência de quê? (Wolff apud Novaes, 2013).}

Os cemitérios das antigas colônias, além de um registro da presença das pessoas, são documentos do passado institucional e, por isso, sua atribuição memorial excede a preservação das memórias individuais, pois também se constituem como um monumento coletivo involuntário que permite nomear os mortos - testemunhas de uma experiência singular no interior das colônias -, completando as lacunas humanas e sociais que o isolamento compulsório gerou. Considerando que são vestígios de uma experiência difícil pouco conhecida, além de assegurarem o culto à memória pela individualização dos mortos, esses cemitérios têm o poder de testemunhar a dimensão coletiva da experiência. Ao simbolizarem os restos de uma política higienista, autoritária, de combate à hanseníase, os cemitérios das antigas colônias, do modo como estão, em sua grande maioria em estado de arruinamento e relegados ao esquecimento, 
assumem um lugar simbólico no "processo de recalque e enterramento do passado"12 (Seligmann-Silva, 2016: 52) vivido e encerrado dentro das instituições.

Como se pode ver na narrativa visual a seguir, montadas com as fotografias tumulares do Hospital-Colônia Itapuã, nem todas as sepulturas estão identificadas, mas muitas resistem à ação do tempo, preservando as inscrições memoriais originais, que asseguram certa identidade com os mortos e expressam laços de afetividade. Algumas possuem inscrições verbais, outras têm retratos, algumas carecem de ambos, outras apresentam as duas formas de inscrição.

\section{Rastros e apagamentos}

“Saudades eternas das tuas irmãs e amigos." Olina (1925 - 1978)

“Sempre amaremos \#\#\#\#\#\#\#\#” Aldo (1939 - 2004)

“Saudades dos filhos" \#\#\#\#\# (\#\#\#\# - \#\#\#\#)

“Saudades de teu amigo \#\#\#\#.” Alcides (1922- 2004)

"Saudade de seu esposo" Irma (1921-1996)

“Faleceu 2308 1970. Saudades dos irmãos.” Simião

“Saudades de teus irmãos.” Merceda (192\#- 198\#)
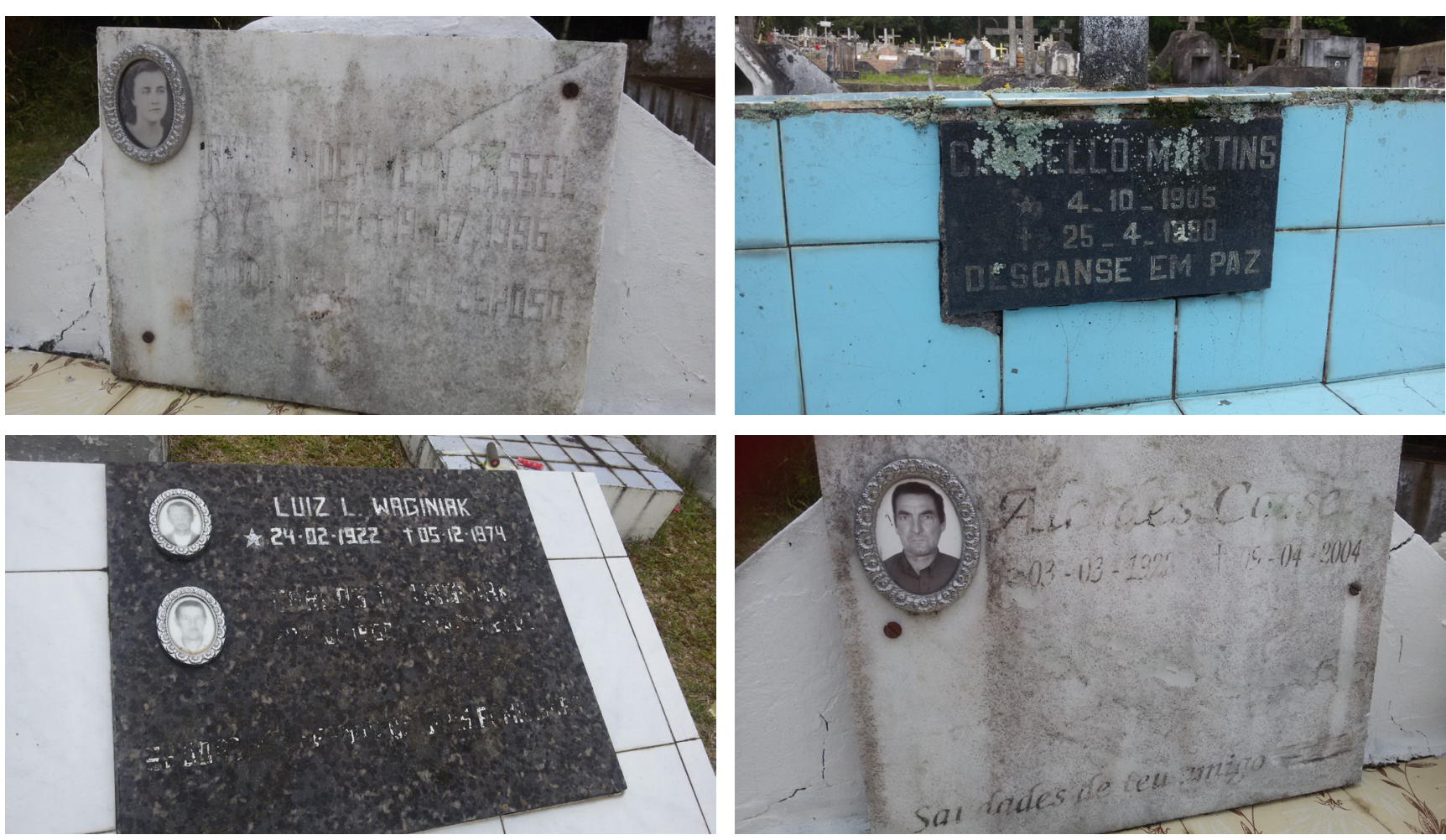

Imagem 2. Prancha montada a partir de fotografias tumulares do Cemitério HCI. Inscrições nas lápides passam por apagamentos. Acervo: Daniele Bezerra, 2019.

${ }^{12} \mathrm{O}$ autor refere-se à função simbólica dos antimonumentos. 

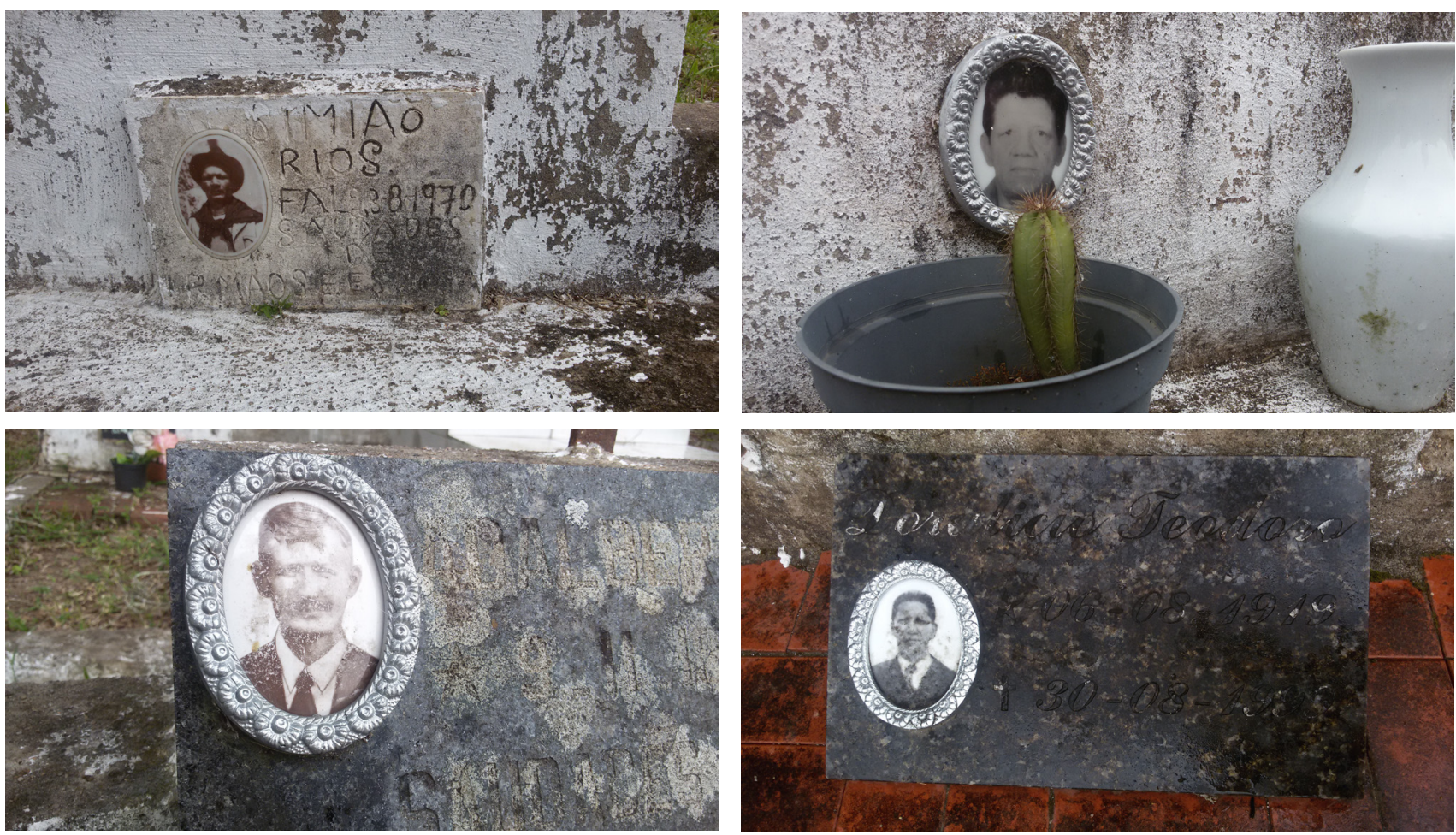

Imagem 3. Prancha montada com fotografias tumulares do Cemitério HCI. Algumas imagens resistem, outras começam a perder-se. Acervo: Daniele Bezerra, 2019.

Em algumas, como se vê na narrativa acima (Imagem 3), as inscrições passam por processos de apagamento relacionados à passagem do tempo e à ausência de gestos de conservação, o que evidencia elos fragilizados com a comunidade dos vivos. Nesse ponto, não há diferença entre o cemitério no interior da colônia e os cemitérios públicos, em que visitas e a renovação dos jazigos costumam ocorrer durante os finados, sendo pouco frequentados durante o resto do ano.

Os cemitérios das antigas colônias, em si, não permitem nominar os mortos de modo objetivo, visto que muitos túmulos não possuem nenhuma identificação ou possuem inscrições canceladas pelo tempo e retratos tumulares corrompidos que salientam ocos pelas suas marcas, como fica evidente nas montagens (Imagem 4 e 5). Mas é justamente esse processo de apagamento silencioso que aponta a relevância da nomeação simbólica dos mortos. Pois a afasia das cidades dos mortos é residual à política de isolamento, e esse silêncio potente declara a presença dos que não podem mais testemunhar. É por isso que consideramos o espaço do cemitério e sua dupla inscrição identitária (túmulos e fotografias tumulares), como uma narrativa silente, apoiada no significado intrínseco dos túmulos, enquanto lugares de memória (Nora, 1981: 26). 


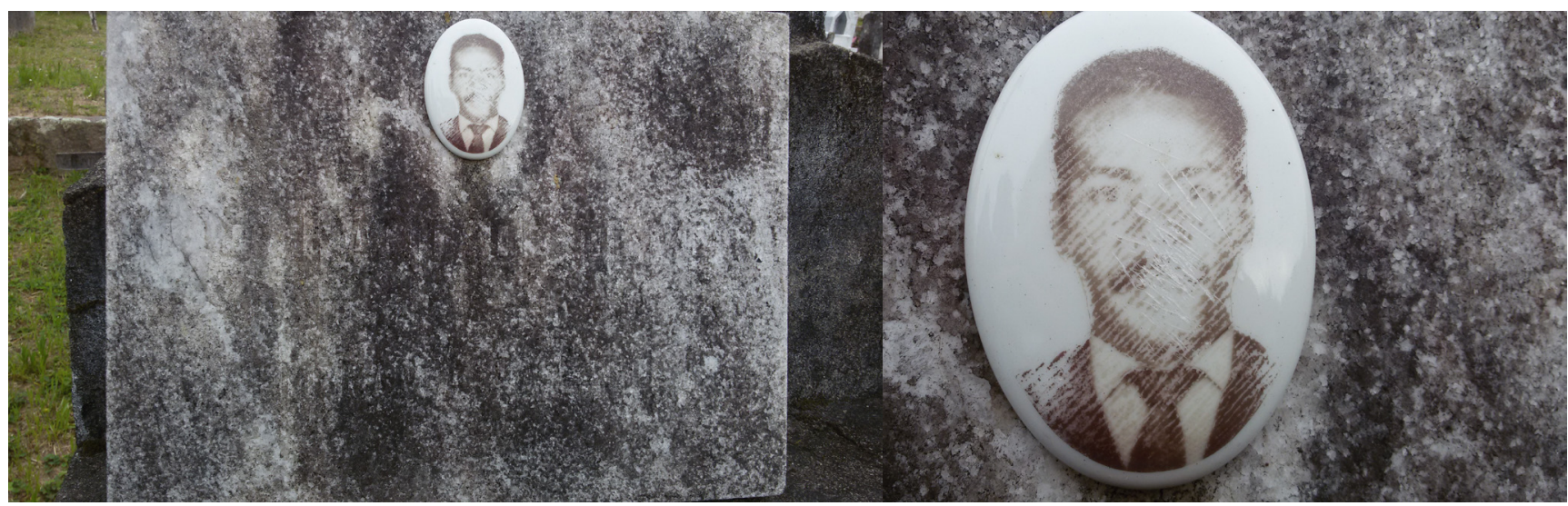

Imagem 4. Prancha montada com a fotografia de uma lápide do Cemitério HCI. A imagem à direita provoca o olhar para o detalhe, em que se observa a superfície arranhada da imagem.

Acervo: Daniele Bezerra, 2019.
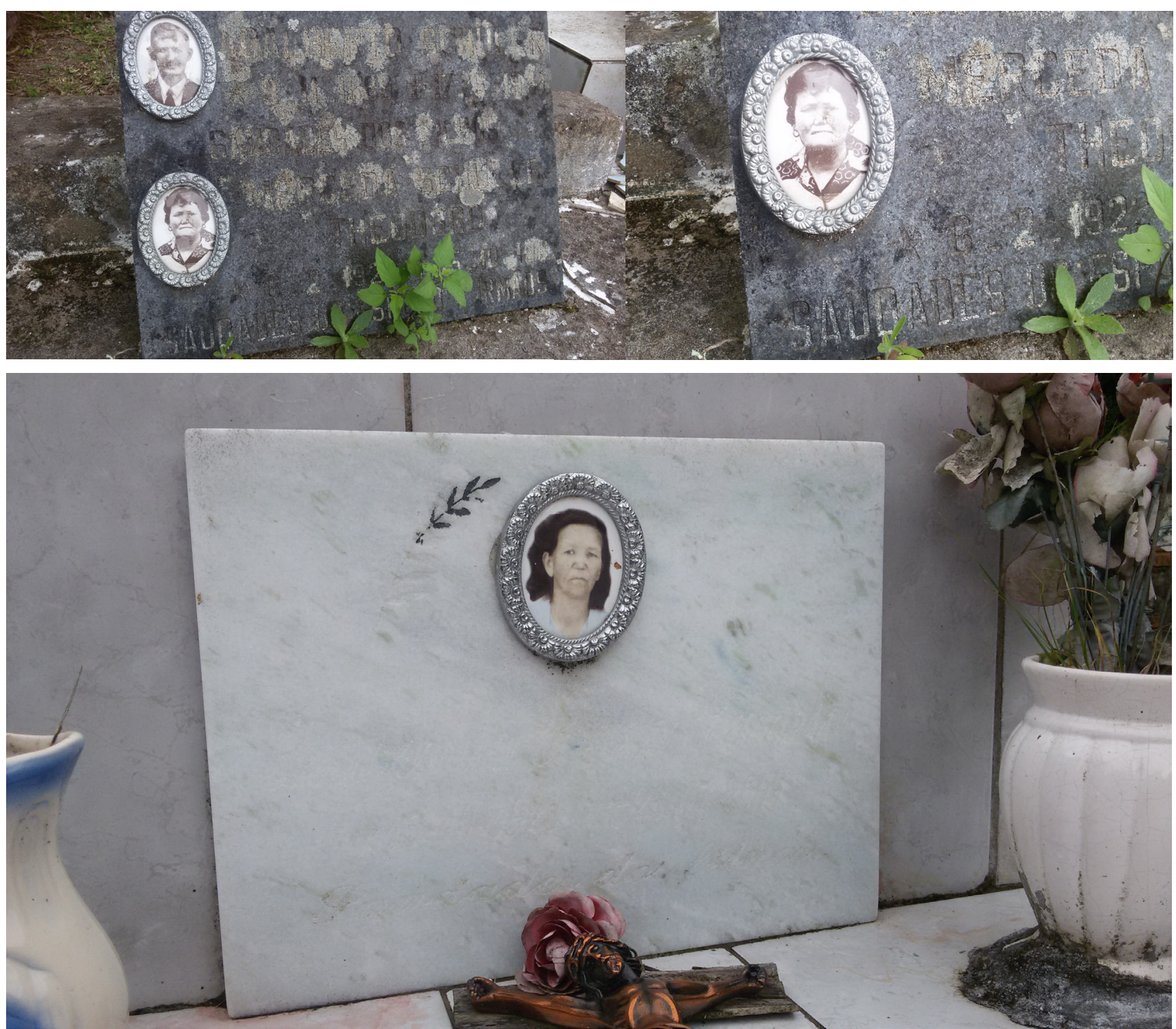

Imagem 5. Montagem feita com imagens tumulares do Cemitério HCI. Detalhes evidenciam o processo de apagamento das informações e a resistência das imagens.

Acervo: Daniele Bezerra, 2019. 
Além disso, se pensarmos que, como efeito colateral de sua tecnologia, os hospitais-colônia invisibilizaram por muito tempo seus moradores, entendemos que os retratos tumulares, além de seu propósito inicial de deter o tempo ao conservar a memória dos mortos, restituem uma imagem do corpo à imaginação. Ao testemunharem a existência (e a ausência) de pessoas que viveram e morreram nesses hospitais, as fotografias fortalecem o testemunho dos túmulos, corporificam ausências e presentificam dimensões esquecidas do passado.

Diante do silêncio, é preciso ser sensível aos ruídos, é o que afirma o filósofo Francis Wolff, pois no silêncio "há presença de sentido" (Wolff apud Novaes, 2013: 50). Ao pensarmos a transmissão da experiência por meio de narrativas silentes, sabemos que o silêncio não é índice de uma presença no passado, como a fotografia, tampouco de ausência, como o túmulo, mas ocupa um lugar intermediário, ambíguo, que testemunha a presença latente de vozes soterradas. Se o sentido do som é o de permitir a identificação de acontecimentos, como afirma Francis Wolff, e, acrescentamos, de integrar a pessoa que ouve à linguagem, percebemos o silêncio simbólico desses espaços de acolhimento da morte tornarem-se signos de um monumento potente. Um silêncio visível, figurado pela ambiguidade da presença/ausência dos mortos, que tanto chama à identificação quanto configura uma forma de transmissão, desde que ativado pelos olhares do presente.

Averiguamos ${ }^{13}$ que, das 2.475 pessoas isoladas no HCI, 878 faleceram no local e, destas, 549 foram sepultadas no cemitério do HCI. Os outros 329 habitantes, após o fim do isolamento compulsório, tiveram a opção de serem sepultados fora do $\mathrm{HCI}^{14}$, como se apenas a morte lhes trouxesse a liberdade definitiva. Voltaremos a falar disso mais adiante. Curiosamente, nada consta a respeito do cemitério e da prática dos sepultamentos no minucioso "Regulamento do HCI", tampouco no "Regimento interno do paciente" (HCI) aos quais tivemos acesso. No entanto, no documento religioso intitulado "Crônicas do Hospital Colônia Itapuã", redigido pelas irmãs franciscanas no decorrer da década de 1940, os sepultamentos são narrados como parte da vida na colônia. As imagens e o trecho da narrativa a seguir permitem reconstituir um desses

\footnotetext{
${ }^{13}$ Averiguações feitas a partir de dados documentados pela historiadora Juliane Serres, entre 2000 e 2001, e dos dados fornecidos pela gestão do HCI, com relação ao período de janeiro de 2007 a janeiro de 2018.

${ }^{14}$ Há ainda, 1.597 ex-pacientes que não se enquadram em nenhum dos casos descritos acima. Inferimos que, exceto o grupo de 21 moradores que segue vinculado ao HCI, os demais estão entre os que se desligaram do Hospital por motivo de alta ou fuga, e não sabemos se estão vivos ou mortos.
} 
momentos, convidando-nos a emergir no espírito do lugar durante um cortejo, conforme se lê a seguir. Na fotografia, nota-se a presença substancial de habitantes vestidos em trajes elegantes, assim como de personalidades religiosas, destacadas pela cor clara de suas vestes. $\mathrm{O}$ cortejo atravessa a microcidade em direção ao cemitério. Na montagem abaixo, (Imagem 6) o cortejo, que ocorreu na década de 1940, se aproxima do limite urbano da pequena cidade, prestes a alcançar a área com maior vegetação onde está localizado o cemitério.
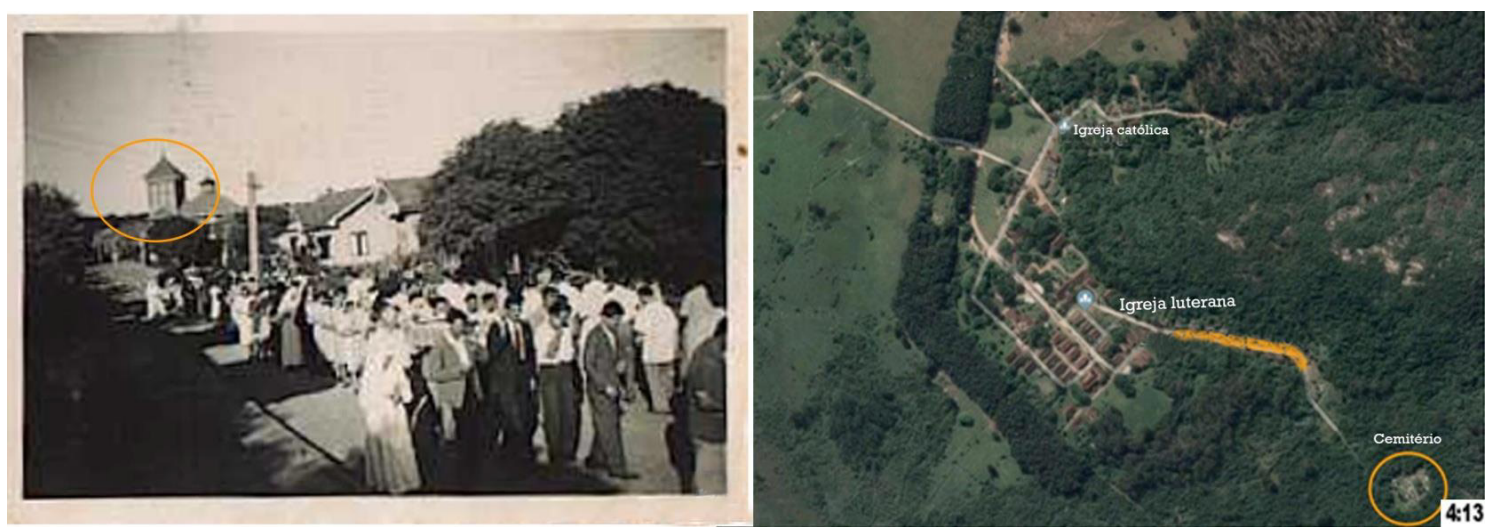

Imagem 6. Montagem para pensar o deslocamento de um cortejo fúnebre no interior do HCI, década de 1940. À esquerda: CEDOPE, HCI, acervo pessoal de Juliane Serres; À direita: Google Maps, 2018. Disponível em: $<$ https://goo.gl/maps/pxynUGii9Rk $>$.

Acervo: Daniele Bezerra, 2019.

\begin{abstract}
No dia 07 de agosto deu-se o primeiro enterro no novo cemitério. Era uma querida, idosa doente, D. Margarida Nedel, que, como primeira achou aqui sua última morada. Seguiram-se no decorrer do ano mais 7, uma senhora e 6 homens [...]. O enterro sempre tem um tanto de impressionante. Todos os internados, exceto os acamados, tomam parte. O cortejo sai da igreja com a cruz na frente, seguido pelo sacerdote e 2 ministrantes com túnica preta, segue a fila dos homens 2 a 2, o esquife, as irmãs, crianças e senhoras. No caminho reza-se o terço em voz alta. Chegados no cemitério segue a encomendação, bênção de sepultura e uma alocução do sacerdote, - e a mãe terra recebe o defunto, o solitário, - nem parente nem amigo pode estar presente. Aí à sombra dos ciprestes e palmeiras, ele espera o dia da ressurreição, o dia de rever com seus entes queridos. Mas não são esquecidos nossos falecidos. As crianças, dos seus passeios trazem flores e enfeitam os túmulos, e muitas vezes vê-se devotos aí, rezando o terço (Crônica, 1940: 4, grifo nosso).
\end{abstract}

Esse fragmento narrativo possui um valor informativo que nos permite observar na mentalidade das irmãs franciscanas a atenção dedicada à memória dos mortos. $\mathrm{O}$ seu compromisso em conservar as identidades indica a indistinção de culto, independentemente da situação liminar que ocupavam em relação à sociedade, e expressa o desejo de que os mortos, sepultados de forma solidária, mas impedidos da presença dos familiares, não fossem desumanizados ou esquecidos. Esse desejo é compartilhado pela comunidade, que participa do cortejo dedicando tempo e atenção ao 
ritual de despedida, o que reforça nosso argumento a respeito da constituição de uma comunidade afetiva no interior das colônias. Além disso, o culto à memória dos mortos é mantido pela comunidade nos dias que se seguem, seja através da presença das crianças que levam flores, seja pela presença dos fiéis que vão até lá rezar o terço.

Observa-se, portanto, que o cerimonial dedicado à "encomendação das almas", a cargo das irmandades religiosas, repercutiu sobre a preservação da memória dos mortos, impondo ao cemitério a função de lembrar, e, com isso, evitando que os falecidos desaparecessem definitivamente por determinação da doença. Pela peculiaridade desses lugares, isso poderia ocorrer, a exemplo de outros hospitais com características asilares, como o Hospital Psiquiátrico São Pedro (RS) e o Hospital de Barbacena (MG), em que os corpos de pacientes, ignorados pela família, eram doados como objeto didático para universidades de medicina.

É claro que, do ponto de vista científico e administrativo, nas primeiras décadas, período em que o isolamento era compulsório, a função do cemitério estava associada ao risco de contágio à população saudável, e, portanto, o cemitério tinha a função de efetivar o isolamento, mesmo na morte. Mas isso não deslegitima a sua função monumental que, com o passar do tempo, agrega novos significados. Ele deixa de apenas preservar memórias individuais, para também representar o testemunho de uma geração acerca do isolamento enquanto política de Estado, num período de transição em que a cura era descoberta, ao mesmo tempo em que muitos morriam devido ao avanço da doença e a ineficácia das drogas. Para os que ainda vivem na colônia, no entanto, o cemitério é uma realidade praticada, o local familiar que demarca a passagem dos amigos e recorda aos vivos sobre o seu destino.

Como havíamos dito antes, do total de 878 habitantes falecidos ao longo da existência do HCI, 329 deles, com condições financeiras e algum apoio familiar, optaram por ser sepultados fora do HCI, após a abertura dos portões. Esse é o caso do Sr. Pedro e sua esposa, falecida um ano e meio antes da nossa conversa, e sepultada no cemitério "Jardim da Paz, perto de Viamão", conforme informação oral ${ }^{15}$. Ao comprarem jazigos em cemitérios fora do HCI, esses habitantes exerceram o direito à reinserção social, que não fora efetivada em vida, uma vez que continuaram a viver sob a tutela do Estado. Com isso, colocam em questão as razões de permanência na colônia após o fim do isolamento compulsório. Afinal, por que sair do HCI após a morte,

\footnotetext{
${ }^{15}$ Narrativa do Sr. PEDRO (pseudônimo), em entrevista concedida a Daniele Borges Bezerra, no HCI, em janeiro de 2017.
} 
quando o fim do isolamento compulsório tornou as saídas possíveis anteriormente? Por que sair do lugar onde se viveu por 60 anos apenas após a morte? A essas questões, o Sr. Pedro respondeu que sua intenção era ir embora, mas que a esposa não quis e por isso ele ficou:

$\mathrm{Na}$ época que eu queria sair, a mulher não quis. Eu também não forcei. Nós começamos a fazer uma casa lá no Gravatá. Quando tava quase pronta ela desistiu e vendemos [risos]. Ela não quis. Aí nós vendemos. Por mim eu tinha ido, experimentar. Mas aí fiquei com a mulher. (informação oral). ${ }^{16}$

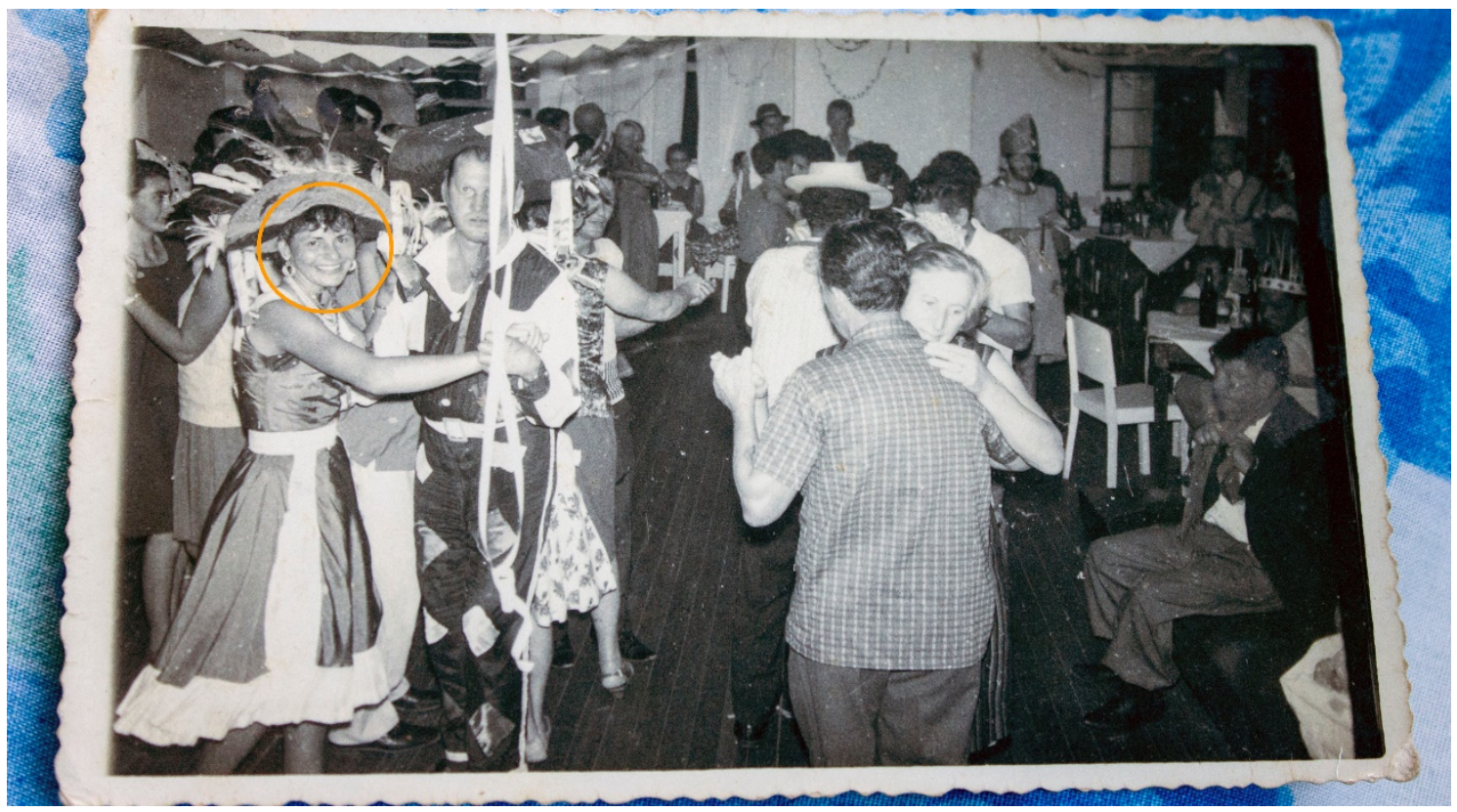

Imagem 7. Leonora (em destaque) dança com o marido em festa na Colônia, década de 1970. Todos falecidos, exceto ela.

Acervo: Daniele Bezerra, 2019.

$\mathrm{Na}$ fala da maioria dos habitantes, o cemitério da Colônia Itapuã está subentendido como uma cidade paralela que acolhe a multidão de vivos que se retira: “Tão tudo morto, só eu de viva aí" (informação verbal) ${ }^{17}$, diz Leonora, referindo-se às pessoas na foto (Imagem 7).

\footnotetext{
${ }^{16}$ Narrativa do Sr. PEDRO (pseudônimo), em entrevista concedida a Daniele Borges Bezerra, no HCI, em janeiro de 2017.

${ }^{17}$ Narrativa de LEONORA (pseudônimo), em entrevista concedida a Daniele Borges Bezerra, no HCI, em janeiro de 2017.
} 
O mesmo ocorre quando Alice mostra seu álbum fotográfico (Imagem 8): “Acho que só resta nós duas. As amigas. Só resta nós duas sentadas no meio, essas outras já foram. E elas todas faleceram aqui" (informação verbal). ${ }^{18}$

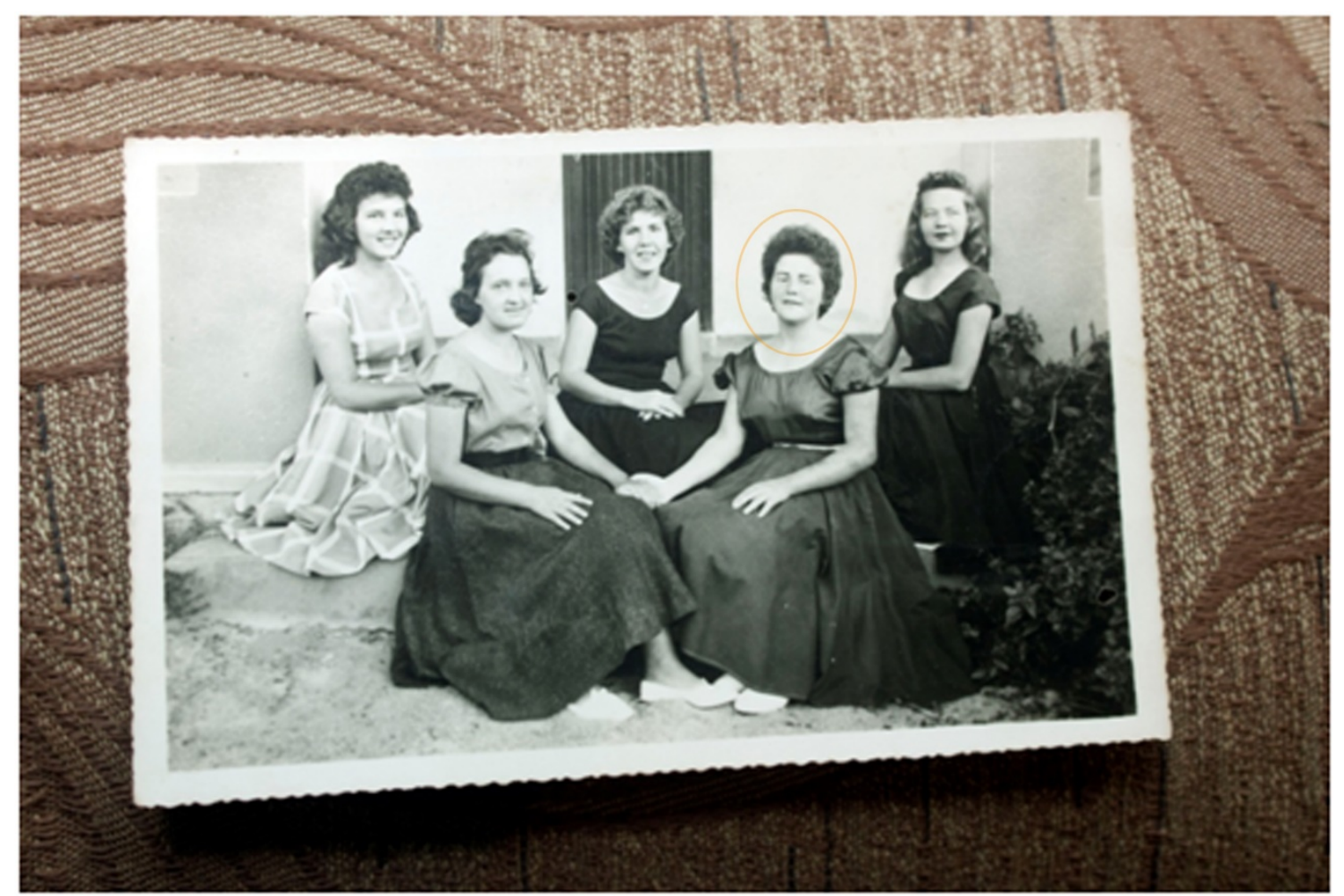

Imagem 8. Alice (destacada na foto) e amigas na Colônia Itapuã, década de 1970.

Arquivo pessoal de Alice.

Acervo: Daniele Bezerra, 2019.

Já para Leonora, o cemitério do HCI é o lugar familiar que guarda a memória de entes queridos e que se tornará a sua morada definitiva: "Tem duas irmãs e o meu velho e mais três cunhados. A minha casa é a primeira que entra ali no cemitério. No que entra na porteira ali, é a minha moradia" (informação verbal). ${ }^{19}$ Dona Ivete também menciona o cemitério indiretamente, ao referir-se aos filhos separados. Ela faz um gesto pesaroso com a cabeça, na direção do cemitério e diz que as vezes acorda e fica pensando nas mães que morreram com "aquele sentimento, sem poder ver os filhos" (informação verbal). ${ }^{20}$ Quem são estas mães que morreram sem poder criar seus filhos e sem jamais terem recebido uma visita destes filhos, “órfãos de pais vivos" (Gomide, 1991), reflexo

\footnotetext{
${ }^{18}$ Narrativa de ALICE (pseudônimo), em entrevista concedida a Daniele Borges Bezerra, no HCI, em janeiro de 2017.

${ }_{19}$ Narrativa de LEONORA (pseudônimo), em entrevista concedida a Daniele Borges Bezerra, no HCI, em janeiro de 2017.

${ }^{20}$ Informação proveniente de conversa informal com IVETE (pseudônimo), ocorrida em 09 de novembro de 2016, quando Daniele Borges Bezerra e o psicólogo da instituição passavam pela sua casa para ir até o cemitério.
} 
de uma ação arbitrária do Estado, conforme Fonseca (2013)? Quem pode garantir-lhes o direito à memória, quando não houver ninguém para reivindicá-la, e apenas as imagens, em processo de cancelamento, sobreviverem como fantasmagorias, desprovidas de qualquer informação?

Atualmente, entre os últimos moradores do HCI, as fotografias são conservadas em seus arquivos privados como objetos afetivos, carregados de recordações. São documentos que afirmam a presença dos mortos no lugar, mas, sobretudo, a existência de uma vida compartilhada em vias de desaparecimento. É isso que o cancelamento proposital das faces da imagem salienta. Quem serão os guardiões dessas memórias, quando os últimos habitantes falecerem? Quem zelará pelas memórias destas identidades em processo de apagamento? Se nada for feito no sentido de conservar as informações existentes, ancoradas nos túmulos e contextualizada pelos últimos moradores, muito em breve estas se tornarão o que Fabiana Bruno (2018) designa por "imagens órfãs".

Esse sentimento é compartilhado pelo Sr. Onofre ${ }^{21}$ que fala da Colônia com nostalgia, não apenas como alguém que morou no local a vida toda, mas como alguém quem lidou com a morte de perto: "Trabalhei doze anos no cemitério de zelador e de coveiro. Agora eles não fazem mais cova, agora é túmulo" (informação verbal). ${ }^{22}$ A percepção do interlocutor é de que está tudo acabando: “era cheio de gente, morreu tudo [...]" (informação verbal). ${ }^{23}$

Durante a conversa com Onofre, a morte é assunto recorrente, seja associado às atividades prazerosas, no auge da microcidade, seja em relação ao sentimento de solidão no presente: “Agora terminou tudo. Não tem mais ninguém aí [...]. Aqui, uma vez, tava bom. Mas tá pra terminar. E, aí, sozinho aí, caminhando na rua. Tem pouca gente caminhando aí. Não passa mais ninguém, só os guardas andam aî" (informação verbal). ${ }^{24}$

A narrativa do Sr. Onofre nos leva a pensar que a sua vivência pregressa como zelador do cemitério acentua a experiência de solidão atual e o sentimento de

\footnotetext{
${ }^{21}$ Natural de Estrela Canabarro, chegou ao HCI com 18 anos, hoje tem 80. Veio com o irmão e uma sobrinha.

${ }^{22}$ Entrevista semidirigida concedida pelo Sr. ONOFRE (pseudônimo), a Daniele Borges Bezerra, no HCI, em janeiro de 2017.

${ }^{23}$ Entrevista concedida pelo Sr. ONOFRE (pseudônimo), a Daniele Borges Bezerra, no HCI, em janeiro de 2017.

${ }^{24}$ Entrevista semidirigida concedida pelo Sr. ONOFRE (pseudônimo), a Daniele Borges Bezerra, no HCI, em janeiro de 2017.
} 
esvaziamento da colônia, com o desaparecimento da comunidade afetiva em que as memórias de uma vida encontram referências. Uma coisa seria trabalhar como coveiro num cemitério municipal, outra coisa é ver as pessoas da sua comunidade irem desaparecendo uma a uma. A sua experiência com a morte coloca em destaque no cotidiano "o poder da ausência e o poder da perda" (Didi-Huberman, 1998: 164), de tal modo que o esvaziamento do espaço da colônia e o crescimento do cemitério são "índices de uma perda" (idem: 148). Não é apenas Onofre que olha para a morte, mas é a morte que lhe devolve o olhar, como diz Georges Didi-Huberman sobre o vazio do túmulo:

\begin{abstract}
“[...] um esvaziamento que aí, diante de mim, diz respeito ao inevitável por excelência, a saber: o destino do corpo semelhante ao meu, esvaziado de sua vida, de sua fala, de seus movimentos, esvaziado de seu poder de levantar os olhos para mim. E que, no entanto, me olha num certo sentido - o sentido inelutável da perda posto aqui a trabalhar (Didi-Huberman, 1998: 37).
\end{abstract}

Com o envelhecimento dos últimos habitantes, a escassez de pessoas que deem continuidade ao culto aos mortos e a ausência de motivação política, a função memorial dos túmulos e de suas fotografias é reduzida. A ausência de políticas de ativação patrimonial desses lugares aprofunda a morte inerente ao esquecimento. Entretanto, enquanto forem acessíveis "à receptividade sensível dos observadores" (Kosseleck, 1998: 61), os monumentos não deixam de enviar uma mensagem, fundada nos signos da morte e da memória.

No HCI, a presença da morte, a relação com o esvaziamento e a sensação de finitude aparecem constantemente nas narrativas dos antigos habitantes, o que podemos entender como consequência dos usos dados ao lugar no presente e da gestão das memórias, que mobilizam um sentimento de finitude e perda. Assim, o fim da vida dos habitantes e o fim da vida do lugar se equivalem, pois apesar do cemitério guardar a memória de quem partiu, em breve não haverá mais pessoas que transmitam as memórias dos mortos para além de suas sepulturas. Nesse sentido, o cemitério sintetiza o patrimônio afetivo do lugar, pois ele é o destino, se não material, simbólico, de uma rede de relações e afetos criada naquele lugar. As fotografias tumulares, por sua vez, exercem a função de ligar o passado ao presente, dando "rostos" para estes personagens quase abstratos do passado no lugar. Fotografias órfãs de pessoas que foram relegadas ao esquecimento no passado, um esquecimento que se processou durante a vida em 
isolamento e que tende a se potencializar no presente, com o esvanecimento dos últimos resquícios de humanidade desses arquivos visuais.

A identificação desses monumentos abandonados torna-se extremamente simbólica de uma intenção de arquivo (Derrida, 2001), pois, por trás do processo, que legitima a peculiaridade do lugar, está o mais impactante e o mais simbólico testemunho do encerramento das funções do hospital, dentro dele mesmo. O valor desses monumentos aos mortos, não está tanto na lembrança que jaz através das lápides, com suas inscrições canceladas pelo tempo, mas na presença considerável de ausências demarcadas pelas fotografias no espaço vazio dos que ali ficaram.

Portanto, esses cemitérios, além de sinalizarem um marco determinante e doloroso na vida das pessoas que passaram pelo isolamento compulsório, documentam um marco da história da doença e comunicam uma dimensão indizível dessa experiência. É por isso que os consideramos, em sua potência narrativa, como um dos dispositivos privilegiados para a condução dessas memórias difíceis. Embora criados para lembrar individualmente, estes monumentos não intencionais nos colocam em contato com a dimensão da perda que tentamos recordar, tanto quanto com a dimensão subterrânea que os antimonumentos se propõem a revelar.

Embora criados para lembrar individualmente, estes monumentos não intencionais nos colocam em contato com a dimensão da perda que tentamos recordar, tanto quanto com a dimensão subterrânea que os antimonumentos se propõem a revelar. Uma "característica" que já podia ser intuída pela aura do espaço. É nesse ponto que o protagonismo dos mortos se faz resistência em imagens ao viverem, simbolicamente, uma segunda vida nas imagens que se cancelam ao longo do tempo. Assim, se como afirma Fabiana Bruno, “as fotografias-órfãs desafiam questões antropológicas ao 'sobreviverem' ou 'superviverem', anonimamente e destituídas de um saber prévio, abandonadas da potência narrativa dos álbuns e histórias/memórias" (Bruno, 2018: 170), estas imagens solitárias, mas ativamente comunicantes, apesar de todo o silêncio que as envolve, também forçam-nos a um compromisso ético de insistir nas circunstâncias de sua existência. 


\section{REFERÊNCIAS}

BARTHES, Roland. A câmara clara. Portugal: Edições 70, 2010.

BENJAMIN, Walter. Charles Baudelaire: Um lírico no auge do capitalismo. São Paulo: Brasiliense, 1989.

. Magia e técnica, arte e política. Ensaios sobre literatura e história da cultura. Obras escolhidas. Volume 1. Tradução de Sérgio Paulo Rouanet. São Paulo: Brasiliense, 1987.

. Passagens. Tradução: Irene Aron. Belo Horizonte: Editora da UFMG, 2018.

BEZERRA, Daniele Borges. A ressonância afetiva das memórias como meio de transmissão para um patrimônio difícil: monumentos em antigos leprosários. 2019. 520f. Tese (Doutorado em Memória Social e Patrimônio Cultural) - Programa de PósGraduação em Memória Social e Patrimônio Cultural, Instituto de Ciências Humanas, Universidade Federal de Pelotas, Pelotas, 2019.

BRUNO, Fabiana. Entre aparições, enigmas e revelações: atos de olhar, escavar e narrar a imagem. Anais do II SIPA Seminário Imagem, pesquisa e antropologia. Campinas: Unicamp. 2018. Disponível em: < https://www.sipa.ifch.unicamp.br/pfsipa/anais_ii_sipa.pdf>. Acesso em 16 de jul. de 2019.

. Cartografia verbovisual da velhice: fotobiografias e montagens de memórias. Revista Chilena de Antropologia Visual. No 10, Santiago, dez.

2007. 30-53 p. Disponível em: $<$ http://www.rchav.cl/2007_10_art02_bruno_\&_samain_por.html\#Layer2 >. Acesso em: 20 de jun. de 2016.

CALVINO, Italo. As cidades invisíveis. Tradução: Diogo Mainardi. São Paulo: Companhia das Letras, 2009.

DEBARY, Octave. Antropologia dos restos: Da lixeira ao museu. Tradução: Maria Leticia Mazzuzzhi Ferreira. Pelotas: UM2, 2017. Disponível em: $<$ https://wp.ufpel.edu.br/ppgmp/files/2016/11/Antropologia-dos-Restos.pdf $>$. Acesso em dez. de 2017.

DERRIDA, Jacques. Mal de arquivo: uma impressão freudiana. Tradução: Cláudia de Moraes Rego. Rio de Janeiro: Relume Dumará, 2001.

DIDI-HUBERMAN, Georges. O rosto e a terra: onde começa o trato, onde se ausenta o rosto. Tradução: Sonia Taborda. Porto Arte: Revista de Artes visuais. Porto Alegre. V.9, nº16 p.61-82, 1998b. Disponível em: < https://seer.ufrgs.br/PortoArte/article/view/27751>. Acesso em 29 de mai. de 2020.

. Cascas. Tradução: André Telles Cascas. Serrote: Uma Revista de Ensaios, Artes Visuais, Ideias e Literatura. São Paulo, no 13, p. 99-133. 2013. Disponível em: 
https://edisciplinas.usp.br/pluginfile.php/4133072/mod_resource/content/1/did_huberma n cascas.pdf. Acesso em 29 de mai. de 2020. 1998. O que vemos, o que nos olha. Tradução: Paulo Neves. São Paulo: Editora 34,

DUBOIS, Philippe. O ato fotográfico e outros ensaios. Tradução: Marina Appenzeller. Campinas, SP: Papirus, 2012.

FONSECA, Cláudia Lee; MARICATO, Glaucia. Criando comunidade: emoção, reconhecimento e depoimentos de sofrimento. Intersecções, Rio de Janeiro, v. 15, n. 2 , p. 252-274, dez. 2013. Disponível em:

$<$ http://www.e-publicacoes.uerj.br/index.php/intersecoes/article/view/9523>. Acesso em 23 de mar de 2018.

GOMIDE, Leila Regina Scalia. Órfãos de pais vivos: a lepra e as instituições preventórias no Brasil: estigma, preconceito e segregação. Tese (Programa de PósGraduação em História da Saúde) Faculdade de Filosofia, Letras e Ciências Humanas. Universidade de São Paulo, São Paulo, 1991.

HAYDON, Kirsten. Antarctic landscapes in the souvenir and jewellery.

2008. Thesis (Doctor of Philosophy)- University Bachelor of Fine Arts - RMIT

University. Candidature Supervisors Robert Baines. Austrália, Melbourne, 2008.

Disponível em: <https://researchbank.rmit.edu.au/eserv/rmit:6690/Haydon.pdf > .

Acesso em jun. de 2018.

KOSSELECK, Reinhart, et al.. Les monuments aux morts comme fondateurs de l'identité des survivantes. Revue de Métaphysique et de Morale, No. 1, Mémoire, histoire (JANVIER-MARS 1998), pp. 33-61 Published by: Presses Universitaires de France Stable URL: http://www.jstor.org/stable/40903577. Acesso em 29 de mai. de 2020.

MAUSS, Marcel. Sociologia e antropologia. Traduzido por: Paulo Neves. São Paulo: Cosac Naify, 2011.

MONTANARELLI, Lisa. In HORNE, Ronald Willian; MONTANARELLI, Lisa. Forgotten Faces. A Window Into Our Immigrant Past. San Francisco: Black and Whit Edition, 2004.

Disponível em: <https:/www.amazon.com/Forgotten-Faces-ImmigrantAmericas-History/dp/0974739529>. Acesso em maio de 2019

NORA, Pierre. NORA, Pierre. Entre memória e história: a problemática dos lugares. Tradução: Yara Aun Koury. In: Projeto história. Revista do Programa de Estudos de Pós Graduados em História e do Departamento de História da PUC- SP. São Paulo: Educ, 1981.

PÉTONNET, Colette. A observação flutuante: o exemplo de um cemitério parisiense. Antropolitica, Niterói, n.25, p.99-111, 2008. 
RANCIÈRE, J. O espectador emancipado. São Paulo: Martins Fontes, 2014.

WOLFF, Francis. O silêncio é a ausência de quê? apud NOVAES, Adauto (org.) Mutações: Treze notas sobre o silêncio e a prosa do mundo, São Paulo: Edições SESC, 2013.

SAMAIN, Etienne. As peles da fotografia: fenômeno, memória/arquivo, desejo. Visualidades, Goiânia, v.10. n.1, p. 151-164, jan-jun de 2012.

SELIGMANN- SILVA, Márcio. Antimonumentos: trabalho de memória e de resistência. Psicologia USP. São Paulo, Vol. 27, n.1, p. 49-60, jan-abr de 2016. Disponível em: http://www.scielo.br/pdf/pusp/v27n1/1678-5177-pusp-27-01-00049.pdf. Acesso em 29 de mai. de 2020.

Recebido: $28 / 01 / 2020$

Aprovado: 15/07/2020 